\title{
Behavior of Alkaline Lipase on Detergency
}

\author{
Kenji Umehara, Yoshikuni Masago, Tsuneharu Mukaiyama, and Osamu Okumura \\ Development Laboratory 2, Lion Corporation \\ (13-12, Hirai 7 Chome, Edogawa-ku, Tokyo, †132)
}

The effects of Aspergillus oryzae lipase on the removal of triolein from fabric were determined from the results of the hydrolysis of triolein.

Aspergillus oryzae lipase was stable in alkaline solutions and in anionic surfactant solutions and particularly so in an $\alpha$-olefinsulfonate (AOS) solution. The removal of triolein from fabric was significantly improved by the addition of Aspergillus oryzae lipase. Aspergillus oryzae lipase hydrolyzed triolein into oleic acid wihtout the accumulation of diolein or monoolein. Results of SEM, EPMA and BSE measurement showed the presence of triolein on the lumen of single cotton fibers. The triolein in these fibers can be removed by Aspergillus oryzae lipase.

\section{Introduction}

A large number of lipases are known to decompose triglycerides. This matter of lipase action in detergent has been studied by many investigators ${ }^{1 \sim 31}$. However, there was no suitable lipase with good activity in alkaline detergent solution. In this paper, the effect of alkaline lipase on the removal of triglyceride from fabric was discussed based on the hydrolysis of the triglyceride.

\section{Experimental}

\subsection{Materials}

$2 \cdot 1 \cdot 1 \quad$ Alkaline lipase

The property of alkaline lipase is shown in Table-1. It was produced by genetically engineered Aspergillus oryzae from NOVO Industri A/S. The lipase activity units quoted were based on a hydrolysis of olive oil emulsion. Measuring procedure is shown in Fig. -1. One lipase unit $(\mathrm{LU})$ is the amount of enzyme which liberates $1 \mu \mathrm{mol}$ of fatty acid from olive oil per minute. Hydrolysis products were determined by the TLC/FID method using an Iatroscan analyzer

Table-1 Property of lipase

\begin{tabular}{c|c}
\hline Activity $(\mathrm{LU} / \mathrm{g})$ & 460,000 \\
\hline Isoelectric point & 4.4 \\
\hline Molecular weight & $\mathrm{ca} .30,000$ \\
\hline
\end{tabular}

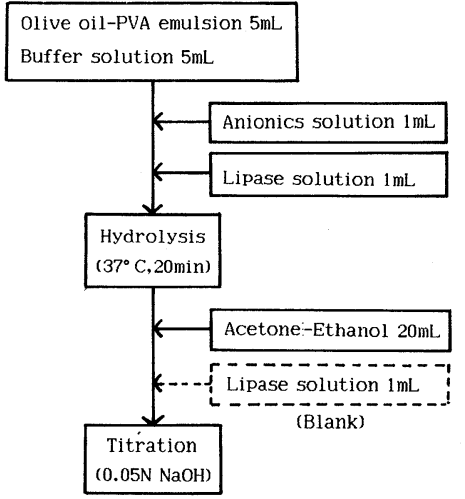

Fig. -1 Measuring method of lipase activity.

(TH-10, Iatron Laboratories, Inc.).

$2 \cdot 1 \cdot 2$ Surfactants

Surfactants used here were sodium $\alpha$ olefinsulfonate, sodium alkylbenzenesulfonate and sodium alkyl sulfate. Alkyl chain length and average molecular weight of them are shown in Table-2.

\section{$2 \cdot 2$ Washing condition}

Washing trials were carried out in a Terg-OTometer (US. Testing Co.) operating under typical Japanese washing condition as shown in Table-3. Each fabric of cotton and polyester was cut into $5 \times 5 \mathrm{~cm}$ swatches. The swatches were soiled with benzene solution of triolein by a micropipette. Residual oily matters on fabric after washing were extracted using a Soxlet 
Table-2 Anionics surfactants

\begin{tabular}{l|c|c|c}
\hline \multicolumn{1}{c|}{ Surfactants } & Alkyl chain length & M.W. & Abbr. \\
\hline Sodium $\alpha$-olefinsulfonate & $\mathrm{C}_{14}-\mathrm{C}_{18}$ & 351 & AOS \\
\hline Sodium alkylbenzenesulfonate & $\mathrm{C}_{10}-\mathrm{C}_{14}$ & 345 & LAS \\
\hline Sodium alkyl sulfate & $\mathrm{C}_{12}$ & 280 & AS \\
\hline
\end{tabular}

Table-3 Washing condition

\begin{tabular}{l|l}
\hline Washing machine & Terg-O-Tometer \\
Rotation & $120 \mathrm{rpm}$ \\
Temperature & $25{ }^{\circ} \mathrm{C} \sim 45^{\circ} \mathrm{C}$ \\
Water hardness & $54 \mathrm{ppm}\left(\right.$ as $\left.\mathrm{CaCO}_{3}\right)$ \\
Presoaking time & $1 \mathrm{~h}$ \\
Washing time & $10 \mathrm{~min}$ \\
Liquor volume & $900 \mathrm{~mL}$ \\
Liquor ratio & 30 \\
\hline Artificial soil & Triolein \\
Clothes & Cotton : Shirting \#60 \\
& Polyester : Amunzen \\
\hline
\end{tabular}

extractor with dichloromethane and then percentage of oily soil removal was calculated as follows :

$$
\operatorname{Removal}(\%)=(W s-W w) / W s \times 100
$$

where $W s$ and $W w$ are the amount of soil on unwashed and washed cloth, respectively.

\subsection{Microscopic analysis}

The adhesion state of oily soil on the fabric was observed by Scanning Electron Microanalyzer (SEM), Electron Probe Microanalyzer (EPMA) and Back Scattered Electron (BSE) with a JXA-8600 (JEOL). When the specimen is bombarded by electrons, characteristic X-ray, backscattered electrons, and secondary electron are produced. Secondary electron images were used to observe the soil particles. Back scattered electron images were used to study the location of oily soil labeled with osmium (VIII). Soiled swatches were prepared with $1 \%$ osmium (VIII) oxide at $25^{\circ} \mathrm{C}$ for $2 \mathrm{~h}$, and dry them at room temperature for $24 \mathrm{~h}$. The double bonds of triolein react with osmium ( VIII) oxide quantitatively ${ }^{4}$, as follows:

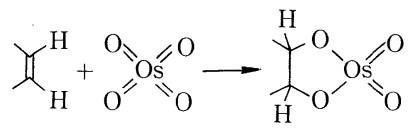

\section{Results and Discussion}

\section{$3 \cdot 1$ Characteristic properties of alkaline lipase}

The stability and activity of enzyme for $\mathrm{pH}$ value and temperature are significant factors ${ }^{5}$ that influence hydrolysis and removal of triolein. The relative activity of alkaline lipase at different $\mathrm{pH}$ values is shown in Fig. -2 and a temperature chart is shown in Fig. -3. For this alkaline lipase, the

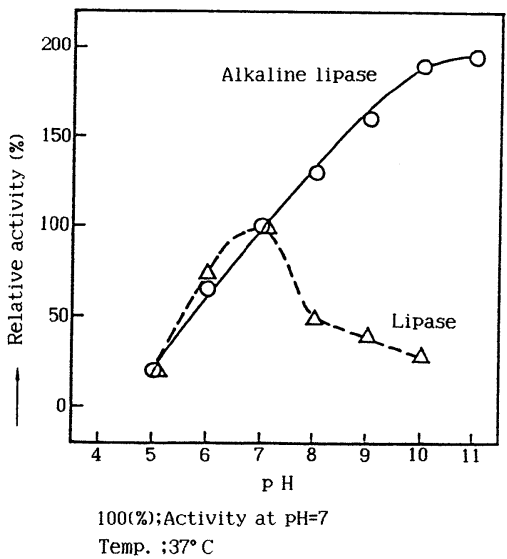

Fig. -2 Activity of alkaline lipase at different $\mathrm{pH}$ values.

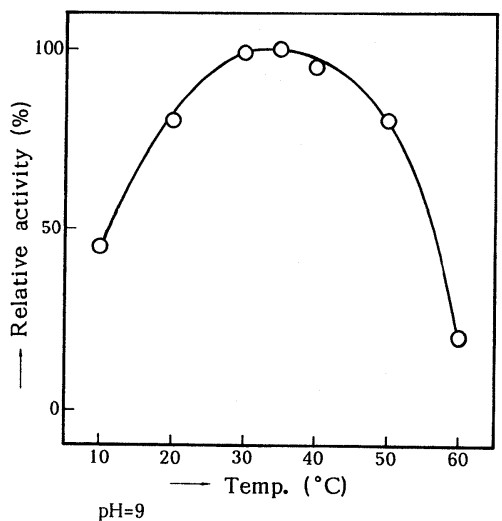

Fig. -3 Activity of alkaline lipase at different temperatures. 


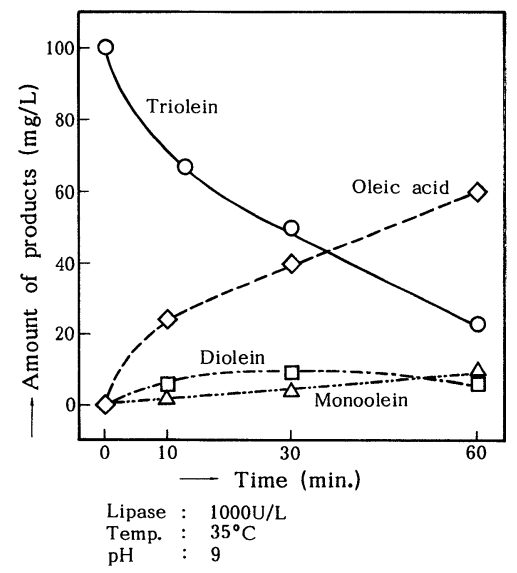

Fig. -4 Effect of reaction time on hydrolysis products.

relative activity rose higher as the $\mathrm{pH}$ increased, and the optimum activity was above $\mathrm{pH} 10$. These peculiar characteristics of alkaline lipase should be noted. In Fig. -3 it was observed that optimum temperature of this alkaline lipase is around $35^{\circ} \mathrm{C}$. At $10^{\circ} \mathrm{C}, 50 \%$ of optimum activity is still retained. Judging from the $\mathrm{pH}$ and temperature charts, alkaline lipase has the most suitable characteristic properties in Japanese cold washing conditions. In order to examine the effect of reaction time on hydrolyzed fragments by the triolein substrate. The study was carried out under the following condition: the concentration of lipase was $1000 \mathrm{U} / \mathrm{L}$ at $35^{\circ} \mathrm{C}, \mathrm{pH} 7$. As shown in Fig. -4, during the hydrolysis of triolein by lipase, the amount of triolein decreased with time. Diolein, monoolein and oleic acid are produced as hydrolysate, only the amount of oleic acid increased with time, while the amount of intermediates of diolein and monoolein hardly increased.

\subsection{The behavior of anionics/lipase system}

In order to investigate an influence of anionics on lipase, AOS, LAS and AS were compared. Fig. -5 illustrates the influence of anionics on lipase activity at concentration of $500 \mathrm{ppm}$ with a reaction time of $20 \mathrm{~min}$. In the AOS/lipase system, $80 \%$ of relative activity is still retained but activity goes down to $50 \%$ in the case of LAS/lipase system. AOS is the most stable for lipase, among them. Fig. -6 shows the lipase residual activity under various anionic surfactant solutions at different incubating times. In general, residual activity deteriorates under anionic

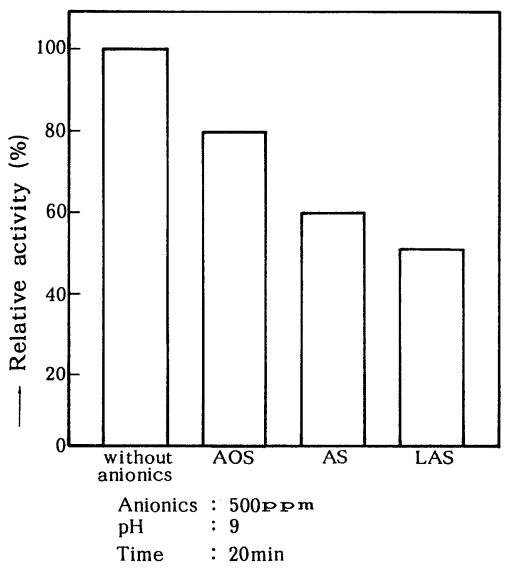

Fig. -5 Influence of anionics on lipase activity.

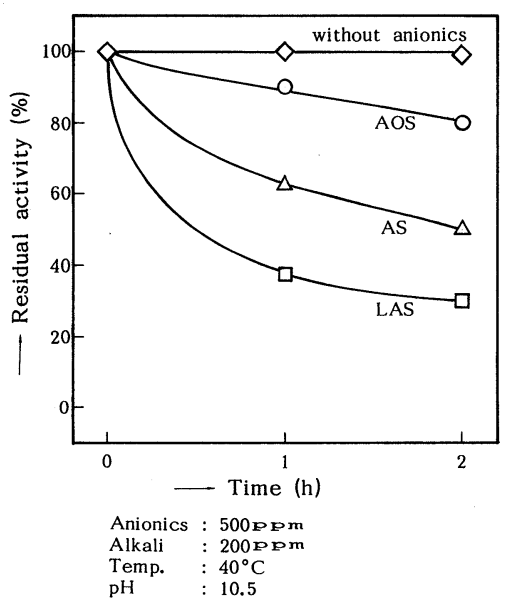

Fig. -6 Influence of incubating time on residual activity.

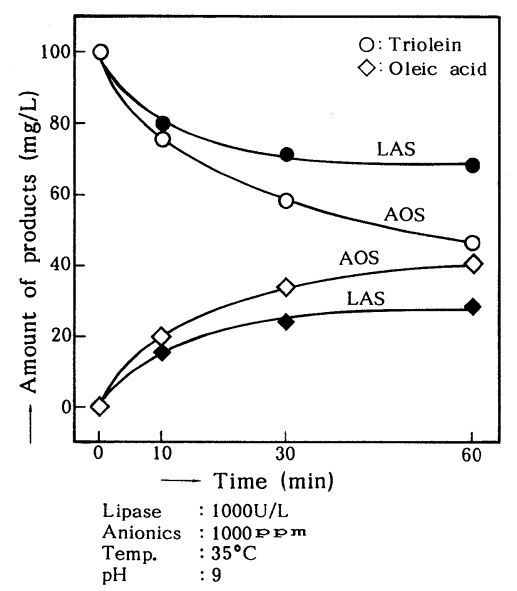

Fig. -7 Effect of reaction time on amount of hydrolysis products at AOS and LAS. 
surfactant solutions with time. After an incubation of $2 \mathrm{~h}$ in the AOS/lipase system, residual activity still remains about $80 \%$, but $50 \%$ and $40 \%$ in case of AS and LAS respectively, in the same incubation time. Fig. -7 shows the effect of reaction time on the amount of triolein and hydrolyzed products in the presence of AOS and LAS. Both the lipase with AOS and LAS decompose the triolein with time. But the AOS/ lipase system decreases the triolein much more than the LAS/lipase system. On the other hand, the amount of oleic acid produced in the AOS/ lipase system is greater than the LAS/lipase system. Based on these results, it can be considered that the AOS/lipase system decomposes the oily soil effectively during washing process. In order to investigate the oil removal ability under realistic washing conditions, AOS and LAS were used. The effect of lipase activity on triolein removal cotton swatches are shown in Fig. -8. Removal of triolein increased as the lipase concentration rose. Removal of triolein of the AOS/ lipase system is much higher than the LAS/lipase system at all lipase concentrations. This is quite coincident with the results of good stability of lipase for AOS. In general, oily soil adhered with synthetic fiber is very difficult to remove, because synthetic fiber has lipophilisity. But the almost same results were obtained using polyester fibers compared with cotton fibers. The effect of temperature on triolein removal of cotton swatches by AOS/lipase system are shown in Fig. -9. The removal of triolein with lipase increases up to

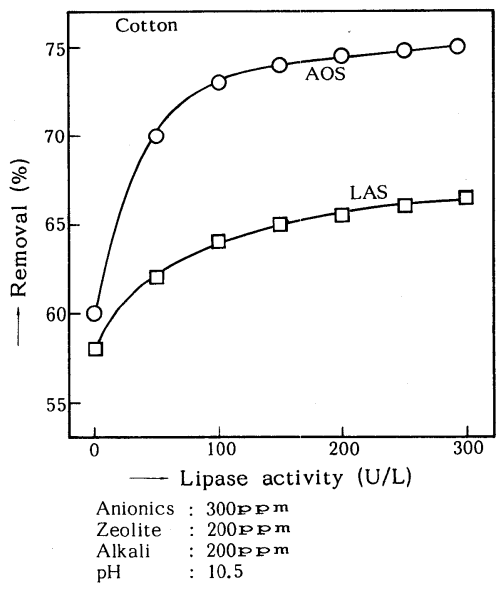

Fig. -8 Effect of lipase activity on soil removal.

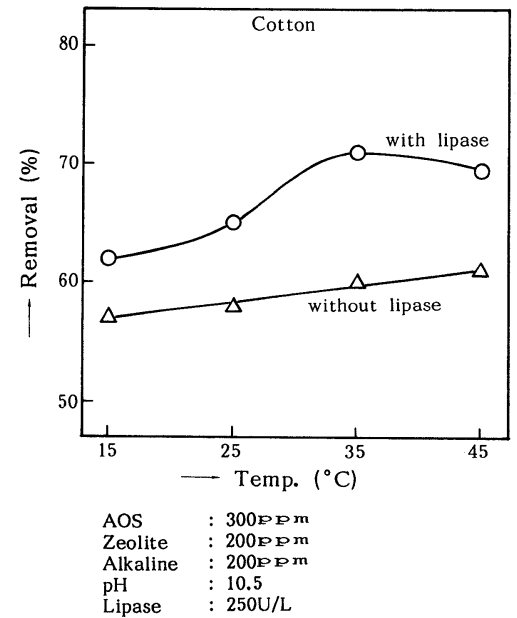

Fig. -9 Effect of temperature on soil removal.

a temperature of $35^{\circ} \mathrm{C}$ but falls slightly at $45^{\circ} \mathrm{C}$ because the lipase activity is also reduced at higher temperature. Compared with and without lipase, detergency with lipase is higher in any case.

\subsection{Microscopic approach}

We used microprobe techniques in order to study the effect of AOS/lipase system on oily soil on the surface and internal of fibers. Fig. -10 shows the SEM and BSE image of cross sections of cotton and polyester fibers soiled with triolein. The left side was examined using an SEM and the right side using BSE at the exactly same spot. The bright area of BSE shows a location of triolein labeled with osmium. Osmium, an element with a high atomic number of 190 , produces

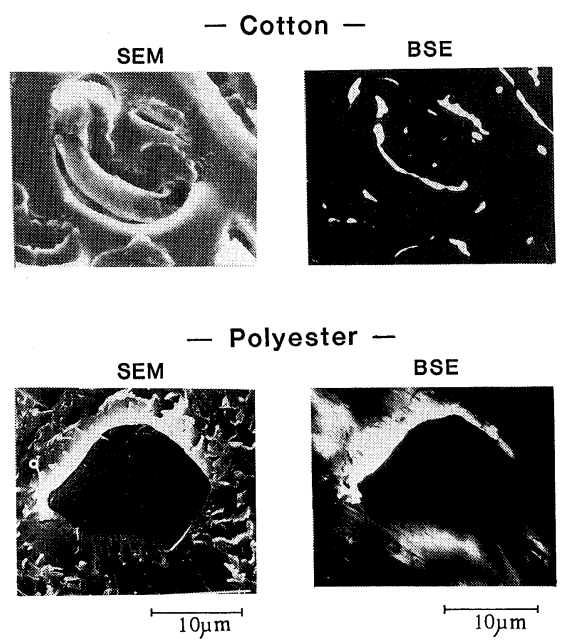

Fig. -10 Cross section of soiled clothes. 
high intensities of backscattered electrons and bright areas. On the cotton single fiber by BSE, the large amount of oily soil is located not only on the surface but also in the internal fiber as lumen. On the other hand, for polyester, the oily soil could be observed dominantly on the surface and fewer in micro porous part. The cross sections of a cotton fiber after washing with or without lipase on AOS based detergent are shown in Fig. -11 . After washing without lipase, large amount of residual oily soil are observed by BSE both on the surface and in the lumen. However, washing
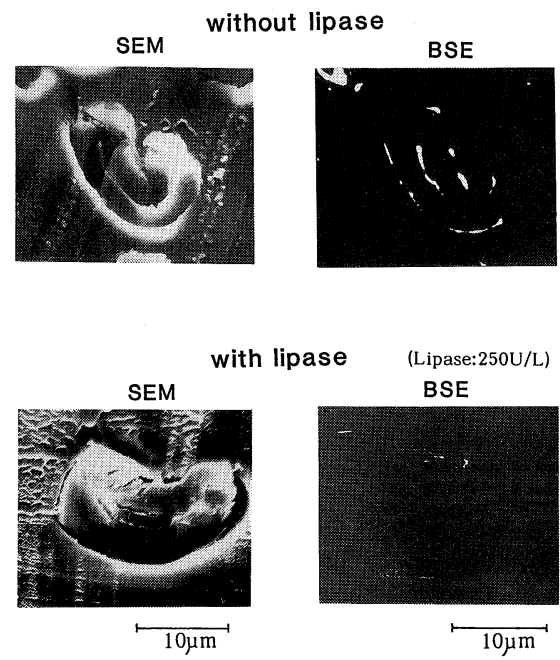

Fig. -11 Cross section of washed clothes - Cotton-
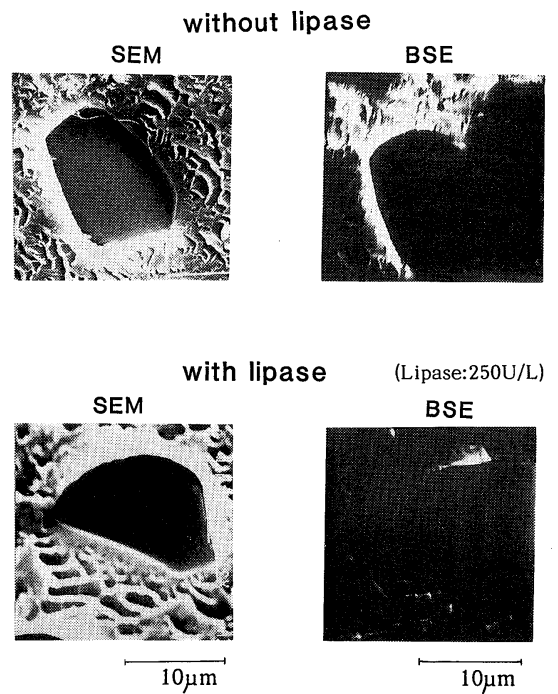

Fig. -12 Cross section of washed clothes - Polyester

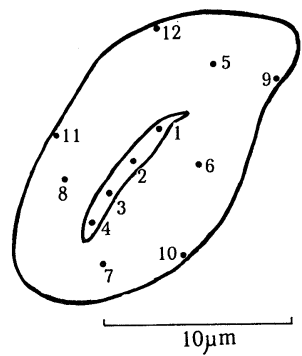

Fig. -13 Locations of X-ray microprobe analysis.

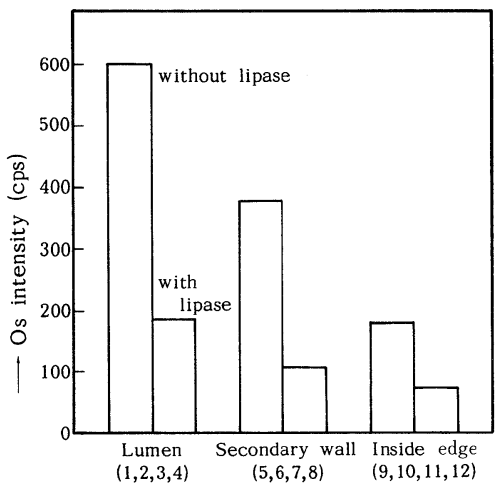

Fig. -14 Relative concentration of triolein at various location.

with lipase detergent, the residual oily soil is significantly lower even in the lumen. The same washing experiments were conducted using polyester as shown in Fig. -12. Almost the same results were obtained as in cotton, oily soil was removed easier by lipase than without lipase. So far, the lumen was a most difficult place to clean with BSE observation. Further detailed experiments were carried out on a cross section of cotton by X-ray count. Intensity of the X-ray energy was $15 \mathrm{keV}$ for $10 \mathrm{~s}$ by placing a spot probe of $0.2 \mu \mathrm{m}$ a diameter. Selected locations are measured as in Fig. -13 , that is, the lumen of fiber is 1 to 4 , the secondary wall is 5 to 8 and the inside edge of fiber is 9 to 12 . Three zones of X-ray counts were calculated as a mean by 4 different spots with and without lipase detergent. The results are shown in Fig. -14. The concentrations of triolein were very different in the locations, the largest amount was retained in the lumen, the secondary wall followed and the smallest amount was on the inside edge. In any place, the X-ray counts washed by lipase detergent were significantly lower than that without lipase detergent. 


\section{Conclusions}

From the study on the characteristic properties of alkaline lipase, the Aspergillus oryzae lipase was stable in alkaline and AOS solution. For this reason, the removal of triolein from cotton and polyester was significantly improved using the AOS/lipase system. It was found from the SEM, EPMA and BSE observations that the large amount of triolein was detected from the lumen of single cotton fibers and AOS/lipase/alkaline detergent could remove it.

(Received Nov.6, 1989)

\section{References}

1) P. Krings et al., Ger. Pat., 2, 021, 529 (1972).

2) T. Tatara, T. Fujii, T. Kawase, and M. Minagawa, J. Am. Oil Chem. Soc., 62, 1053 (1985).

3) T.Fujii, T. Tanaka, and M. Minagawa, J. Am. Oil Chem. Soc., 63, 796 (1986).

4) A. Zlatkis et al., "A Concise Introduction to Organic Chemistry”, McGraw-Hill Kogakusha Ltd. (1973) p. 76.

5) O. Okumura and M. Mukaiyama, J. Jpn. Oil Chem. Soc. (Yukagaku), 36, 754 (1987).
アルカリリパーゼの洗浄挙動

梅原謙二・真子義邦 $\cdot$ 向山恒治 $\cdot$ 奥村 統

ライオン株式会社 第 2 開発研究室

(テ132 東京都江戸川区平井 7-13-12)

Aspergillus oryzae リパーゼのトリオレイン除去に対す る効果についてトリオレインの加水分解を基に研究し た。

Aspergillus oryzae リパーゼは，アルカリ溶液，ア二オ ン界面活性剤溶液, 特に $\alpha$-オレフィンスルホン酸ナト リウム $(\mathrm{AOS})$ 溶液中で安定であった。トリオレイン の除去は, Aspergillus oryzae リパーゼの添加により大幅 に増大した。Aspergillus oryzae リパーゼはトリオレイン を，ジオレイン，モノオレインの蓄積なしにオレイン酸 にまで加水分解した。SEM, EPMA, BSE の観察から, トリオレインは綿単繊維内部のルーメンにまで入り込ん でいることがわかった。Aspergillus oryzaeリパーゼ/ $\mathrm{AOS} /$ アルカリ系はこれを除くことができる。 